\title{
Public 'say on pay' activism in South Africa: Targets, challengers, themes and impact
}

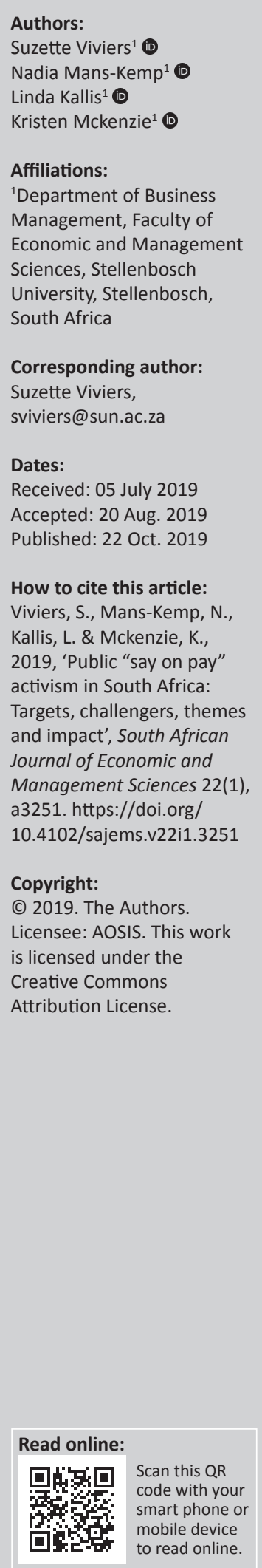

Background: Shareholders and other stakeholders in South Africa are increasingly raising their concerns in public about seemingly excessive executive remuneration. Most of their criticism is rooted in the large and growing wage gap in the country.

Aim: The authors investigated the nature of the entities whose executive remuneration policies and practices were publicly criticised, the types of challengers involved in this social movement, key issues raised and the impact that the challengers had on the targeted executives' remuneration.

Setting: Public activism involving five South African state-owned enterprises and 38 companies listed on the Johannesburg Stock Exchange.

Methods: Executives and entities that were targeted in public were identified from three online financial newspapers published between 01 January 2010 and 31 December 2016. A total of 92 events were recorded involving 65 executives. Data on these executives' emolument and three control variables were sourced from Bloomberg. Descriptive statistics and mixedmodel analysis of variance tests were employed to evaluate the quantitative secondary data.

Results: In line with the extant literature, most of the targets were large, well-known companies. Individual and minority shareholders represented the largest category of challengers, followed by asset managers and trade unions. The vast majority of concerns centred on the size and composition of executives' packages and insufficient justifications provided by remuneration committees. The total pay, bonuses and other performance-based incentives decreased significantly in the year after the companies were publicly targeted.

Conclusion: The findings suggest that public 'say on pay' activism can be an effective mechanism in addressing seemingly excessive executive emolument.

Keywords: Executive remuneration; public shareholder activism; negative press coverage; total pay; bonuses; performance-based incentives.

\section{Introduction}

'Say on pay' is an important element of shareholder democracy and has been the topic of a growing body of academic literature in recent years (Cai \& Walkling 2011; Conyon \& Sadler 2010; Goranova \& Ryan 2014). 'Say on pay' is a legal term that refers to the rights of ordinary shareholders to influence the executive remuneration policies and practices of the companies in which they invest (henceforth called 'investee companies') (Cai \& Walkling 2011). Evidence in the United States (US) suggests that shareholders had raised their concerns regarding seemingly excessive executive remuneration as far back as 1933 (Marens 2002). Interest in the topic surged post-2008 as many stakeholders believed that the structure of executives' emolument packages contributed to the global financial crisis (Bhagat \& Bolton 2014; Faulkender et al. 2010).

'Say on pay' is not only a phenomenon that occurs elsewhere in the world. Shareholders in South Africa have also joined this social movement which encourages fair and responsible executive remuneration (Viviers 2015). Although the country celebrates 25 years of democracy in 2019 , the sad reality is that economic freedom remains beyond the grasp of many ordinary citizens. According to a 2017 survey published by Statistics South Africa, poverty levels in the country have risen sharply after the 2010 recession. In 2015, more than half of the population (55.5\%) was categorised as 'poor' (Statistics South Africa 2017). South Africa also has one of the highest wage gaps in the world (Statistics South Africa 2017). It reflects the difference between the remuneration received by the highest paid employee in a company, usually the chief executive officer (CEO) and the lowest paid employee. The wage gap of locally listed companies increased from 61.8 times in 
2017 to 64.7 times in 2018 (PwC 2018). This large and growing wage differential contributes to South Africa having the highest level of income inequality in the world (The World Bank in South Africa 2018). Discontent is subsequently rising among shareholders about remuneration at the highest corporate echelons, notably excessive CEO pay (Ertimur, Ferri \& Muslu 2011; Kimbro \& Zu 2016).

In addition to social movement theory (Reid \& Toffel 2009), previous scholars have used various other theoretical foundations to address the multidimensional nature of shareholder activism (Goranova \& Ryan 2014). The agency theory is deemed the primary theoretical lens in activism literature (Goranova \& Ryan 2014). This theory is also tied to executive remuneration literature, suggesting that managers should be incentivised to maximise shareholder value (Jensen \& Meckling 1976). Some shareholder activists express dissatisfaction with the disconnect between performance and emolument and demand that remuneration policies be amended (Goranova \& Ryan 2014). Pay-performance sensitivity is dependent on achieving a so-called 'optimal contract' to attract and appropriately incentivise talented executives (Bussin 2015a).

Local companies often justify their generous pay packages to executives by citing the intense competition to attract and retain skilled executives from a limited talent pool (Bussin 2018; Madlela \& Cassim 2017). Although this claim may be valid in some cases, fundamental questions regarding social justice remain. The wage gap can be addressed from both ends of the pay scale. Whereas trade unions can negotiate higher wages for the lowest paid individuals (Banning \& Chiles 2007), shareholders can influence the size and composition of executives' pay packages (Conyon \& Sadler 2010), albeit through a non-binding vote.

The emergent voice among South African shareholders and other stakeholders (collectively called 'challengers') might be ascribed to a number of events including the Marikana massacre. This tragic incident, which occurred in August 2012, is seen by some as a turning point in South African history. Alexander (2013:605) posits that this event initiated a 'massive wave of strikes which are changing [the] structures that shape people's lives'. In addition, the surge in civilian and student protests in recent years (Bohler-Muller et al. 2017) might have emboldened social-minded activists to add their voices to the debate on what constitutes fair and responsible executive remuneration (Keke 2017). Although protests can highlight pressing issues, they should occur in an organised, controlled manner. Ideally, messages should be conveyed with minimal disruption to the economy.

A number of public and private voice mechanisms are available to shareholder activists to hold managers accountable and bring about change in investee companies (Yocam \& Choi 2010). Private voice mechanisms comprise confidential correspondence and negotiations with investee companies, whereas public voice mechanisms include the filing of shareholder resolutions, voting, asking questions at shareholder meetings and raising concerns in the traditional and social media (Viviers 2015). Proxy contests and legal proceedings to enforce shareholder rights could also be regarded as formal voice strategies (Viviers 2015). Most prior studies have investigated the effectiveness of 'say on pay' resolutions and voting in the US and the United Kingdom (UK) (Conyon \& Sadler 2010; Del Guercio, Seery \& Woidtke 2008). Few studies have been conducted internationally on public opinion and the 'power of the pen' in transforming executive remuneration policies and practices (Core, Guay \& Larcker 2008; Hooghiemstra, Kuang \& Qin 2015; Kuhnen \& Niessen 2012).

Most of the studies that have been conducted on executive remuneration in South Africa have centred on the relationship between CEO compensation and company performance (Bussin \& Blair 2015; Bussin \& Modau 2015; Bussin \& Nel 2015; Bradley 2013; Deysel \& Kruger 2015; De Wet 2012; Scholtz \& Smit 2012). Other scholars have investigated the factors influencing remuneration policies such as pay benchmarking (Oberholzer \& Theunissen 2012) and the retention of talented staff, especially black executives (Nzukuma \& Bussin 2011). Limited research has been conducted on the influence that shareholders could have on shaping executive remuneration policies and practices (Madlela \& Cassim 2017; Viviers 2015).

In light of the research gap, the authors formulated four research objectives, namely to investigate the nature of the South African entities that were publicly criticised for their executive remuneration policies and practices, to identify the main challengers in this social movement, to highlight the key issues they raised, and to determine the impact that challengers had on the targeted entities' executive remuneration. The study covered five state-owned enterprises (SOEs) and 38 companies listed on the Johannesburg Stock Exchange (JSE) over the period 2010-2016. If shareholders and other stakeholders realise that their actions can democratise executive remuneration in South Africa, more of them might be encouraged to speak out in public.

In the following section, pertinent literature will be discussed on the nature of the entities that are typically targeted and the challengers who participate in this social movement. Attention is also given to the executive remuneration-related issues raised by the challengers and studies outlining the effectiveness of shareholder activists as change agents. Next, the methods used to collect and analyse secondary quantitative data are presented. This is followed by the main findings and conclusions along with recommendations for remuneration committees, academics and 'say on pay' challengers.

\section{The nature of entities being targeted}

Although several international scholars found that large companies and those with poor financial performance are 
targeted the most (Cai \& Walkling 2011; Ertimur et al. 2011; Goranova \& Ryan 2014), no evidence in this regard could be established locally (Viviers \& Smit 2015). Companies that were excluded from the FTSE/JSE Responsible Investment (RI) Index in 2013 attracted significantly more 'against' votes than their counterparts that were included. Listed South African companies that recorded low environmental, social and governance (ESG) disclosure scores, as computed by Bloomberg, also received several 'against' votes (Viviers \& Smit 2015). Barko, Cremers and Renneboog (2018) likewise established that US companies with low ESG ratings were more likely to be targeted. These targets typically had a high market share, enjoyed considerable analyst coverage, had high stock returns and were frequently traded. Engagements often resulted in ESG rating being adjusted (Barko et al. 2018).

\section{Challengers in the 'say on pay' movement}

As large institutional investors own the majority of listed shares globally, they have a responsibility to monitor corporate behaviour and intervene where deemed necessary (Goranova \& Ryan 2014). These powerful financial intermediaries tend to be better informed, have easier access to investee companies' boardrooms and have more clout to drive institutional change than individual and minority shareholders (Gifford 2010; Schnatterly, Shaw \& Jennings 2008). As elsewhere in the world, institutional investors in South Africa prefer to engage behind closed doors (Yamahaki \& Frynas 2016). The term 'institutional investor' refers to asset owners, such as pension funds and insurance companies, and the asset managers who are appointed to act on their behalf. The authors acknowledge that asset owners could provide debt and equity financing to investee companies. The focus in this article is, however, only on asset owners' role as shareholders.

In large markets, shareholder activists can use an exit (divestment) strategy. If a shareholder sells a significant stake in an investee company and announces this decision publicly, a clear message is sent to management. In addition, a publicly announced divestment can considerably influence the target company's market valuation (Gillan \& Starks 2000; Stathopoulos \& Voulgaris 2016). An exit strategy might, however, go unnoticed when a shareholder divests without informing the market of the reasons for doing so. As South Africa has a relatively small stock market, very few shareholders have used this strategy (Viviers \& Smit 2015).

Minority shareholders and other challengers, such as trade unions and non-governmental organisations, often find it difficult to secure private meetings with investee companies. As a result, they are limited to asking questions at shareholder meetings and raising their concerns in the press. By 'airing a company's dirty laundry' in public, these challengers often succeed in obtaining swift responses to their questions and transformation requests (Viviers, Mans-Kemp \& Fawcett 2017). It should be noted that minority shareholders enjoy extensive legal protection in South Africa. The Companies Act (No. 71 of 2008) even enables them to bring a class action suit against an investee company.

Research conducted by Gantchev (2013) and Stathopoulos and Voulgaris (2016) shows that, as societies are becoming more justice-oriented, more expressions of public discontent are being observed. Nowhere is this public discontent more prevalent than in relation to executive remuneration (Davids \& Ntamane 2017). The controversy has even been described as being at 'the cutting edge of the [US] shareholder spring' (Corkery \& Medarevic 2013).

Anecdotal evidence suggests that there has been a notable increase in the number of companies that received a large percentage of 'no' votes on their remuneration policies since the publication of the King IV report. Compared to earlier versions of the report, King IV introduced more principled guidelines on the structure, approval and disclosure of executive remuneration policies and practices. Boards should ensure that executive emolument is fair and responsible in the context of overall employee compensation and are obliged to engage with shareholders should the remuneration policy attract more than $25 \%$ opposing votes (Institute of Directors in Southern Africa [IODSA] 2016). Research shows that few opposing votes were cast at local investee companies in the past (Viviers \& Smit 2015). Examples in this regard include MTN Group, Old Mutual and ABSA Group (Mchunu 2019).

\section{Theoretical link between shareholder activism and executive emolument}

The agency theory is the primary theoretical lens in activism literature (Goranova \& Ryan 2014). There are different views on the agency theory when applied to executive remunerationrelated activism. Remuneration could arguably be used to align executives' interests with those of shareholders, by designing contracts that reward superior performance (Bussin 2015a; Jensen \& Meckling 1976). Carefully structured executive pay packages could provide a potential solution to the agency problem and diminish agency costs (Bebchuk \& Fried 2006; Devers et al. 2007).

Substantial bonuses that are unjustified, however, have the potential to considerably reduce shareholders' wealth (Bebchuk \& Fried 2006). Remuneration committees are criticised for increasing CEO compensation despite poor financial results (Bussin 2015a). A prominent driver of shareholder activism is the lack of financial performance at investee companies (Goranova \& Ryan 2014). The perceived misalignment between a company's financial performance and executive pay furthermore provokes discontent among shareholders, as it represents a lost opportunity to alleviate the agency problem (Cai \& Walkling 2011; Ertimur et al. 2011). Incentive-based compensation thus necessitates enhanced monitoring by directors and shareholders (Goranova \& Ryan 2014). 
The need for greater alignment between executive remuneration and company performance gave rise to the optimal contracting theory (Bussin 2015a). Based on this theory, remuneration committees often defend seemingly excessive executive remuneration packages given the need to attract and retain highly qualified individuals from a limited talent pool (Edmans \& Gabaix 2009). Advocates of this theory seek to achieve greater pay-performance sensitivity (Bussin 2015a). Managerial power is an alternative theory related to the drivers of executive compensation (Bussin 2015a). This theory suggests that executives could benefit from large pay packages, as they could partly influence the structure of their packages (Bebchuk \& Fried 2003; Edmans \& Gabaix 2009). Given executives' negotiation power, the remuneration committee could be forced to serve their best interests (Bussin 2015a). Executives could subsequently receive rewards that are less than optimal from a shareholder's perspective (Bussin 2015b). As managerial power could contribute to the agency problem (Bebchuk \& Fried 2003), shareholder monitoring and engagement are essential (Bussin 2015b).

Most engagements on the topic relate to the misalignment between company performance and executive pay (Bussin 2015a; Cai \& Walkling 2011; Ferri \& Sandino 2009). Not only did activists question the size of executives' remuneration packages, but they also requested more information about the metrics that were being used to evaluate and reward these individuals' performance (Conyon \& Sadler 2010; Liu \& Taylor 2008). Scholars attribute the high level of discontent to shareholders observing 'a lost opportunity to alleviate the agency problem' (Goranova \& Ryan 2014:1243). Other challengers were guided by self-transcendent values (Jansson \& Biel 2011) such as social justice and fairness. Executives have also been blamed for excessive risk-taking to optimise their stock option income at the expense of shareholders (Burns \& Kedia 2006; Ertimur et al. 2011).

\section{The effectiveness of shareholder activists as change agents}

In one of the first studies on the impact of shareholder activism on executive remuneration, Thomas and Martin (1999) investigated 168 shareholder proposals submitted to 145 US companies over the period 1993-1997. They noted that boards responded by lowering their CEO pay levels and package composition. Challengers tended to target poorly performing companies that exhibited higher levels of executive compensation in comparison to their industry peers. Almazan, Hartzell and Starks (2005) confirmed a negative relationship between total direct compensation and the concentration of active institutional shareholders among US companies in the 1990s. Direct compensation included salaries, bonuses, options and stock grants, long-term incentive plans and other sources of compensation. In 2004, shareholder activists targeted more than 150 US companies to adopt fair value accounting for employee stock options. In the cases where shareholders approved these proposals, the level of CEO compensation decreased along with the stock options that were used to reward these CEOs (Ferri \& Sandino 2009).
In line with previous researchers, Ertimur et al. (2011) investigated 1198 shareholder proposals on executive emolument in the US. These authors, however, also assessed the outcomes of 134 'just vote no' campaigns over the period 1997-2007. Their findings concurred with those of Kimbro and $\mathrm{Zu}$ (2016) who showed that shareholder activists' efforts resulted in remuneration committees reducing excessive CEO pay. Contrasting findings were reported by Conyon and Sadler (2010) who investigated 'just vote no' campaigns in the UK from 2002 to 2007. They reported little evidence that CEO pay was substantially lower in companies that were previously targeted. This finding could be partly explained by Cai, Garner and Walkling's (2010) observation that 'say on pay' campaigns were often used to focus on large, visible companies and not necessarily on those with excessive CEO pay.

Instead of analysing voting outcomes, Bauer, Moers and Viehs (2015) studied the extent to which shareholders withdrew their proposals prior to a company's annual general meeting (AGM). Their sample included 12000 shareholder proposals filed to Standard \& Poor's 1500 companies between 1997 and 2009. Proposals were usually withdrawn when shareholders were satisfied with the management's response to their questions or the commitments made to transform. Withdrawn proposals on executive compensation were associated with subsequent amendments to pay practices.

Whereas the previously mentioned studies focused on shareholder proposals and voting as public voice activism mechanisms, Core et al. (2008) investigated the role of the press in shaping executive remuneration in the US. These authors considered more than 11000 press articles on CEO compensation over the period 1994-2002. They noted that the press coverage was related to company size and large option exercises. However, they found no evidence that negative reporting motivated the considered companies to change their executive compensation practices. In a European context, Hooghiemstra et al. (2015) observed that negative press coverage of CEO pay packages predicted shareholder discontent and subsequent 'say on pay' votes. Their study highlighted the important role of the press in promoting corporate governance, including responsible compensation practices.

As indicated earlier, the majority of studies on executive remuneration in South Africa have focused on the relationship between executive pay and company performance. As this link is not always clear, shareholders and other challengers have become increasingly critical of local companies' executive pay policies and practices (Viviers 2015). It is essential that shareholders monitor executive pay packages (Bussin 2015b), especially as executives have considerable power to influence their own pay (Bussin 2015a). In addition to total pay, Bussin (2015a) suggested that pertinent attention should be given to the components of executives' emolument packages. Given that the agency theory is the prominent theoretical lens in activism literature (Goranova \& Ryan 2014), 
the focus of this study was on 'say on pay' activism. The authors acknowledge that executive emolument could be an instrument to address the principal-agent problem, but could also be part of the problem (Bebchuk \& Fried 2003). The relationships between public shareholder activism and various executive pay components were thus investigated. Given their negotiation power and growing public scrutiny, focus was specifically placed on CEO compensation.

In line with Core et al. (2008), the following research hypotheses were formulated:

$\mathbf{H}_{0,1}$ : There is no relationship between public 'say on pay' activism and changes in the total pay of targeted executives.

$\mathbf{H}_{0,2}$ : There is no relationship between public 'say on pay' activism and changes in the bonuses and other performance-based incentives of targeted executives.

$\mathbf{H}_{0,3}$ : Public 'say on pay' activism does not have a larger effect on the total pay of CEOs than non-CEOs.

$\mathbf{H}_{0,4}$ : Public 'say on pay' activism does not have a larger effect on the bonuses and other performance-based incentives of CEOs than non-CEOs.

\section{Research methods}

This descriptive study firstly focused on the nature of local entities that were publicly criticised for their executive remuneration policies and practices over the period 01 January 2010 to 31 December 2016. Focus was also placed on the main challengers in the social movement, the key issues raised and the impact that the challengers had on the targeted entities' executive remuneration policies and practices.

An Excel database was created to capture data from relevant online newspaper articles. The required data were hence available in the public domain. Keywords and phrases were used to identify articles from three prominent South African finance publications, namely Fin24, Business Day and Moneyweb. The keywords and phrases were: shareholder engagement, public shareholder activism, shareholder concern(s), shareholder discontent, proxy voting, wage gap, executive remuneration, cash bonus(es), performance-based incentive(s), AGM, shareholder meeting and ordinary resolution. Keywords also included the names of well-known local shareholder activists such as Theo Botha, Chris Logan, David Couldridge and the Public Investment Corporation (PIC). As the press cannot be considered a homogeneous information source in predicting shareholders' 'say on pay' voting behaviour (Hooghiemstra et al. 2015), a decision was made to exclude articles that appeared in the general press.

The following data were captured: the name of the targeted JSE-listed company or SOE, name of the targeted executive, name of the shareholder activist, name of the newspaper featuring the article, the publishing date of the article and the activist's specific concerns. Only articles featuring activists' apprehensions about executive remuneration were included, whether raised at a shareholder meeting or during an interview with a journalist. Different newspapers often reported the same criticism levelled against a particular executive or company. In such cases, only the most complete article was considered. To ensure the accurate classification of topics, two of the authors compared their individual classifications with each other.

A total of 92 events were identified involving 65 executives. Most of these individuals were only targeted once or twice during the entire research period. In some articles mention was only made of 'executives' without revealing their names. Data on the two dependent variables (total pay, and bonuses and other performance-based incentives) were then downloaded for each of the targeted executives in the year when they were criticised and one year later. The latter enabled the authors to determine the impact that the challengers had on changing executive remuneration policies and practices. Although Core et al. (2008) included stock options in their study, insufficient data were available on share options for South African executives. All values were recorded in South African rand at financial year end. Values were adjusted for inflation using South Africa's Consumer Price Index average for each year of the research period.

In line with Core et al. (2008), the following control variables were considered: company size (log of total assets) and company performance (as reflected by the total revenue and earnings before interest and tax). Data on the dependent and control variables were downloaded from Bloomberg L.P. (2018) for the 38 JSE-listed companies and manually recorded for the five SOEs based on their published financial statements. Data were also captured on the industry in which a listed company operated (using the Global Industry Classification Standard) and whether the company was a constituent of the Top 100 and FTSE/JSE RI indices in the year that it was targeted. To test $\mathrm{H}_{0,3}$ and $\mathrm{H}_{0,4}$ a one (1) was allocated for targeted executives who were CEOs, and a zero (0) for those who were not.

An inductive process was followed to identify the main categories of challengers and remuneration-related concerns that were raised during the research process. This form of content analysis was deemed appropriate as there are, as far as could be ascertained, no previous studies on the phenomenon in the local context (Elo \& Kyngäs 2007). Descriptive statistics were computed to evaluate trends in the data, whereas mixedmodel analysis of variance (ANOVA) tests were used to examine the research hypotheses. To ensure their anonymity, no names of the targeted companies, SOEs or executives were reported in this article.

\section{Ethical considerations}

Stellenbosch University's Research Ethics Committee (Humanities) granted ethical clearance for this project on 18 June 2018 (project and clearance number: REC-2018-6925). As no humans were involved in the study, the ethical risks associated with the project were deemed to be minimal. 


\section{Results}

The results are discussed according to the four research objectives proposed earlier.

\section{The nature of entities being targeted}

The executive remuneration policies and practices of the following five SOEs were publicly criticised at some point during the research period: the national electricity provider (ESKOM), the national broadcaster (SABC), PetroSA, Transnet and the South African National Roads Agency (SANRAL). Executives at 38 JSE-listed companies were targeted, including those at Telkom. Although this provider of fixed-line, mobile, data and information technology services is listed on the local bourse, the South African government owns the majority of its issued ordinary shares.

Most of the listed companies did business in the financial $(33.7 \%)$ and materials industries (16.3\%). Labour unrest in the mining industry could be partly blamed on the widening wage gap between mining executives and other employees (Bussin 2018; Seccombe 2013). A few of the targeted companies $(12.5 \%)$ had their primary listings on stock exchanges other than the JSE, notably in London. This distinction is important as a London-based listing might imply that executives are compensated in pound sterling rather than in South African rand. At an exchange rate fluctuating between R15 and R20 to the pound, these executives' packages might seem exorbitant in local terms, but they are quite in line with those of their UK peers.

The vast majority of the targeted companies (73.68\%) ranked among the 100 largest JSE-listed companies. This finding is not surprising as previous researchers have also noted that large companies are more likely to be targeted than small ones (Core et al. 2008). According to Brandes, Goranova and Hall (2008) and Ferri and Sandino (2009), activist campaigns involving large companies have a better chance of capturing public and media attention, thus facilitating spillover effects. These authors argue that non-targeted companies tend to address contentious issues to avoid similar, potentially damaging public criticism.

Half of the targeted companies were constituents of the FTSE/ JSE RI Index. The authors expected a smaller percentage of constituents to be targeted, as these companies are supposedly responsible corporate citizens. It was thus anticipated that their executive remuneration policies and practices would be more transparent and socially justifiable.

\section{Challengers in the 'say on pay' movement}

Table 1 provides an overview of the different types of activists who raised their executive remuneration-related concerns in public.

As expected, the largest group of challengers consisted of individual and minority shareholders. These shareholders generally do not have access to corporate decision-makers and are hence forced to ask questions at shareholder meetings or speak to journalists. The most vocal activists in this category were Theo Botha, Chris Logan, Roy McAlpine and Albie Cilliers. It is encouraging that more asset managers are articulating their 'say on pay' concerns in public. Their visible approach might be due to private engagements that were unsuccessful. This claim, however, calls for further investigation.

Given the nature of the investigated topic, it came as no surprise that trade unions were important challengers. As large asset owners, they have an important monitoring role and responsibility to voice concerns regarding fair emolument on behalf of their members. Trade unions have long been regarded as social movements in themselves as they strive to promote fairness in labour markets (Masiya 2014; Watson 2007). The involvement of challengers who do not have a financial interest in the targeted companies (such as politicians and thought leaders) might be ascribed to their desire to bring about a more just society. The freedom to openly express their views could be construed as a sign of a healthy democracy.

\section{Prominent executive remuneration-related issues raised by challengers}

As illustrated in Table 2, most of the 'say on pay' concerns related to the size of executives' total pay, bonuses and other performance-based incentives.

Almost $30 \%$ of public outcries by challengers related to insufficient or lacking justifications for the size or composition of executives' emolument packages. Challengers were particularly critical of companies that increased their executives' total pay, bonuses and other performance-based

TABLE 1: Number of 'say on pay' events based on activist type.

\begin{tabular}{|c|c|c|c|c|c|c|c|c|}
\hline Type of activist & 2010 & 2011 & 2012 & 2013 & 2014 & 2015 & 2016 & Total \\
\hline Individual and minority shareholders $\dagger$ & 6 & 4 & 6 & 1 & 10 & 9 & 10 & 46 \\
\hline Asset managers末 & 1 & 1 & - & 2 & 1 & 5 & 9 & 19 \\
\hline Trade unions $\S$ & 2 & - & 3 & - & 1 & 1 & 4 & 11 \\
\hline Politicians & - & 4 & - & - & - & - & 6 & 10 \\
\hline Others & 2 & - & - & - & - & - & 3 & 5 \\
\hline Total & 11 & 9 & 9 & 3 & 12 & 16 & 32 & 92 \\
\hline
\end{tabular}

$\dagger$, Reference was often only made to minority shareholders without citing names; $\$$, Asset managers who raised their concerns in public included the Public Investment Corporation (PIC), Mergence Investment Managers, Allan Gray, Element Investment Managers, Aeon Investment Management, Old Mutual and Prudential Asset Managers; $\$$, Trade unions that featured in this study included Investment Managers, Allan Gray, Element Investment Managers, Aeon Investment Management, Old Mutual and Prudential Asset Managers; $\$$, Trade unions that featured in this study included
the National Union of Mineworkers (NUM), the Congress of South African Trade Unions (COSATU), the Association of Mineworkers and Construction Union (AMCU) and the South African Commercial, Catering and Allied Workers' Union (SACCAWU); $\uparrow$, This category included a pension fund consultant, a thought leadership organisation, the Institute of Directors in Southern Africa (IODSA), the Black Management Forum and an investor interest group. 
incentives while financial performance stagnated or declined. This finding corroborates prior research in the international context (Cai \& Walkling 2011; Core 2008; Ferri \& Sandino 2009). Several activists also requested greater clarity on the metrics and time frames that are used to determine (and hence justify) performance-based incentives.

\section{The effectiveness of activists as change agents}

The mixed-model analysis of variance test results for the first two hypotheses are shown in Table 3.

$\mathrm{H}_{0,1}$ could be rejected in light of the significant positive relationship observed between the variables. The average annual total pay of executives decreased from R30 200583 to R26 545361 after being publicly targeted. The positive relationship between public 'say on pay' activism and change in the bonuses and other performance-based incentives of executives meant that $\mathrm{H}_{0,2}$ could also be rejected. The average annual monetary value of these compensation elements fell from R15 234711 to R10 580657 in the year after being targeted. These findings highlight the important monitoring

TABLE 2: Categories summarising challengers' executive remuneration-related concerns.

\begin{tabular}{|c|c|c|c|}
\hline Main concern & Sub-category concerns & $N$ & $\%$ \\
\hline \multirow{7}{*}{$\begin{array}{l}\text { Size of total } \\
\text { package or } \\
\text { individual } \\
\text { elements } \\
\text { thereof }\end{array}$} & Size of total pay package & 54 & 20.69 \\
\hline & Size of bonus and other performance-based incentives & 38 & 14.56 \\
\hline & The growing wage gap & 8 & 3.07 \\
\hline & Level of fixed pay & 5 & 1.92 \\
\hline & Rate of change of pay & 5 & 1.92 \\
\hline & Size of severance packages & 2 & 0.77 \\
\hline & Total & 112 & 42.91 \\
\hline \multirow{6}{*}{$\begin{array}{l}\text { Justifications } \\
\text { provided by } \\
\text { remuneration } \\
\text { committee }\end{array}$} & $\begin{array}{l}\text { Justification of remuneration in light of poor company } \\
\text { performance }\end{array}$ & 32 & 12.26 \\
\hline & $\begin{array}{l}\text { Justification of bonus in light of poor company } \\
\text { performance }\end{array}$ & 18 & 6.90 \\
\hline & $\begin{array}{l}\text { Unsatisfactory link between executive pay and } \\
\text { company performance }\end{array}$ & 9 & 3.45 \\
\hline & Justification of remuneration packages in general & 12 & 4.60 \\
\hline & $\begin{array}{l}\text { Unjustified amount of benefits included in total } \\
\text { remuneration package }\end{array}$ & 6 & 2.30 \\
\hline & Total & 77 & 29.50 \\
\hline \multirow[t]{6}{*}{ Transparency } & Lack of disclosure on performance-based pay & 18 & 6.90 \\
\hline & Inaccurate disclosure of bonuses & 13 & 4.98 \\
\hline & Lack of disclosure of compensation policy & 11 & 4.21 \\
\hline & Lack of transparency on total pay & 7 & 2.68 \\
\hline & Non-compliance with the King III remuneration guidelines & 6 & 2.30 \\
\hline & Total & 55 & 21.07 \\
\hline \multirow{5}{*}{$\begin{array}{l}\text { Composition } \\
\text { of packages }\end{array}$} & Excessive use of stock options and shares & 7 & 2.68 \\
\hline & Retirement benefits & 4 & 1.53 \\
\hline & $\begin{array}{l}\text { Overreliance on short-term performance such as } \\
\text { bonuses }\end{array}$ & 4 & 1.53 \\
\hline & Vesting period of stock options & 2 & 0.77 \\
\hline & Total & 17 & 6.51 \\
\hline Total & & 261 & 100 \\
\hline
\end{tabular}

role that shareholders and other challengers play in promoting fair and responsible executive remuneration in South Africa.

Almost two-thirds of the targeted executives (64.45\%) were CEOs. This finding was expected. Other scholars also noted that these individuals experience more public scrutiny, given that they usually earn more than other directors (Nordén \& Strand 2011). The statistics did not reveal that public 'say on pay' activism had a larger effect on the total pay $\left(\mathrm{H}_{0,3}\right)$ or bonuses and other performance-based incentives $\left(\mathrm{H}_{0,4}\right)$ of CEOs compared to non-CEOs (CEOs: $F(2,710)=0.543 ; p=0.583$ and non-CEOs: $F(2,761)=2.086 ; p=0.131)$. Although the majority of CEOs earned more than their non-CEO counterparts and were targeted more frequently during the study period, it does not seem as if the remuneration committees differentiated between CEOs and non-CEOs when adjusting pay packages. Challengers might have focused their attention on CEOs to make a statement about executive remuneration in general, and not only on the individuals in question. In light of the managerial power theory, it could be argued that although shareholders recognise the considerable power of CEOs in influencing remuneration policies and practices, remuneration committees are not as sensitive about the matter.

\section{Conclusions and recommendations}

Executive remuneration remains a controversial topic and regularly features in newspaper headlines. Despite a growing body of literature on shareholder activism and executive remuneration, few studies have considered the intersection between these fields. Most local studies focused on the pay-performance link, composition of executive remuneration packages and pay benchmarking. This study is the first of its kind in that it adopts a social movement perspective and offers empirical evidence on the targets, challengers, themes and the impact of public 'say on pay' activism in South Africa.

The first research objective called for the identification of the local entities that were targeted by 'say on pay' activists over the research period 2010-2016. A rigorous data collection process revealed that five large SOEs and 38 JSE-listed companies were publicly scrutinised. In line with the extant literature, most of these targets were large, well-known companies.

The research furthermore centred on identifying and categorising the key challengers in the local 'say on pay' social movement. As expected, individual and minority shareholders represented the largest category of challengers, followed by asset managers and trade unions. As individual and minority shareholders generally do not have access to

TABLE 3: Mixed-model analysis of variance test results for $\mathrm{H}_{0,1}$ and $\mathrm{H}_{0}$

\begin{tabular}{|c|c|c|c|c|c|}
\hline Hypothesis & Effect & $\begin{array}{c}\text { Numerator } \\
\text { degrees of freedom }\end{array}$ & $\begin{array}{c}\text { Denominator } \\
\text { degrees of freedom }\end{array}$ & $F$ & $p$ \\
\hline $\begin{array}{l}\mathrm{H}_{0,1} \text { : There is no relationship between public 'say on pay' activism and changes in the total pay of } \\
\text { targeted executives. }\end{array}$ & Time & 2 & 166 & 3.53 & 0.031* \\
\hline
\end{tabular}

$*$, Significant at the $95 \%$ confidence level; $* *$, Significant at the $99 \%$ confidence level. 
boardrooms, they have no choice but to raise their concerns in public. It is a pity that only a handful of individual and minority shareholders actively speak out. Shareholders of all sizes are encouraged to take a more public stance on executive remuneration as their efforts could just be what is required to promote fair and responsible executive remuneration.

The third research objective focused on the key 'say on pay' issues raised in the press. The vast majority of concerns centred on the size and composition of executive pay packages. Insufficient communication by remuneration committees, especially in cases where companies increased their executives' pay despite poor company performance, also featured prominently. The empirical evidence in this study showed that some shareholders did not view executive compensation as a means of addressing the agency problem, but rather as a contributing factor. Challengers who do not have a direct financial stake in the targeted companies might be raising their concerns on broader social grounds. This argument is bolstered by the finding that most of the targeted executives were CEOs. As supported by Kidder and Buchholtz (2002), these individuals play a major role in creating trust, both within and beyond their organisations. Seemingly excessive compensation could thus be detrimental not only to their own reputation, but also to their companies' reputation. By targeting figureheads, challengers in this study addressed executive pay in general, rather than focusing on specific cases.

The authors also investigated the impact that challengers had on the targeted executives' remuneration. The statistics showed that total pay, and bonuses and other performancebased incentives decreased significantly in the year following negative press coverage. No differences in decreases were observed between CEOs and non-CEOs.

The findings suggest that public 'say on pay' activism could be effective in addressing the large and growing wage gap in South Africa. The authors acknowledge that private engagement might have a significant impact on the decisions of remuneration committees. Given that private correspondence and negotiations between institutional investors and companies are typically confidential, scholars do not have access to data on the nature and effectiveness of these engagements. The empirical evidence could nonetheless encourage shareholders of all sizes to take a stronger public stance on seemingly excessive and poorly justified executive pay packages.

The findings contradict claims that requests by individual shareholders, or 'gadflies' as they are known in the US, 'waste managerial time and cost firms millions of dollars' (Gantchev \& Giannetti 2019:1). The evidence also refutes allegations that these shareholders only seek 'fame' by questioning and criticising directors at AGMs (Nordén \& Strand 2011). A growing number of remuneration committees of local entities might be more attentive to these challengers as they realise the importance of preserving their company's reputation and subsequent ability to attract capital, consumers and employees in a relatively small market.
Given the empirical evidence, a number of recommendations are offered. Remuneration committees of South African SOEs and listed companies should take cognisance of the growing 'say on pay' movement. They could avoid damaging publicity by improving their reporting, especially pertaining to the metrics they use to determine bonuses and other performance-based incentives. This recommendation is made despite claims that increased disclosure could result in pay benchmarking and an upward spiral in total executive compensation (Cadman \& Carter 2014). Shareholders, trade unions and other stakeholders are entitled to more transparent explanations of seemingly excessive remuneration. This recommendation is particularly apt in cases where an entity's wage gap is far in excess of the industry or national average. In a country plagued by inequality, 'say on pay' clearly extends beyond discussions on addressing the agency problem, as it effectively touches on the moral fibre of society. Remuneration committees should ideally engage with institutional investors prior to AGMs to inform them about relevant matters and clarify questions that they might have.

Scholars could extend this pioneering research by including expression of discontent made via social media. It is expected that a growing number of stakeholders will use this platform in future to convey their discontent. More research is also required on best practices for report details on executive pay policies and practices. Challengers should be emboldened by the fact that public 'say on pay' activism not only raises awareness of key issues, but that it can effectively reduce the total executive pay, bonuses and other performance-based incentives. Shareholders of all sizes and other concerned parties are thus encouraged to make greater use of their democratic right to speak out freely: Viva 'say on pay' democracy in South Africa!

\section{Acknowledgements}

The authors would like to thank Prof. Martin Kidd for his assistance with the statistical analysis. A special word of gratitude is also extended to Dr Ruth Albertyn who critically reviewed the manuscript.

\section{Competing interests}

The authors have declared that no competing interests exist.

\section{Authors' contributions}

S.V. conceptualised the study and wrote most of the article. L.K. and K.M. sourced relevant literature and constructed the database. N.M.-K. wrote certain sections of the literature review and took responsibility for the technical requirements, including referencing.

\section{Funding}

This research received no specific grant from any funding agency in the public, commercial or not-for-profit sectors. 


\section{Data availability statement}

Data sharing is not applicable to this article as no new data were created or analysed in this study.

\section{Disclaimer}

The views and opinions expressed in this article are those of the authors and do not necessarily reflect the official policy or position of any affiliated agency of the authors.

\section{References}

Alexander, P., 2013, 'Marikana, turning point in South African history', Review of African Political Economy 40(138), 605-619. https://doi.org/10.1080/03056244. 2013.860893

Almazan, A., Hartzell, J.C. \& Starks, L.T., 2005, 'Active institutional shareholders and costs of monitoring: Evidence from executive compensation', Financial Management 34(4), 5-34. https://doi.org/10.1111/j.1755-053X.2005.tb00116.x

Banning, K. \& Chiles, T., 2007, 'Trade-offs in the labor union-CEO compensation relationship', Journal of Labor Research 28(2), 347-357. https://doi.org/10.1007/ BF03380050

Bauer, R., Moers, F. \& Viehs, M., 2015, 'Who withdraws shareholder proposals and does it matter? An analysis of sponsor identity and pay practices', Corporate Governance: An International Review 23(6), 472-488. https://doi.org/10.1111/ corg.12109

Barko, T., Cremers, M. \& Renneboog, L, 2018, 'Shareholder engagement on environmental, social and governance performance', SSRN, viewed 13 April 2019 from https://www.ssrn.com/abstract=2977219.

Bebchuk, L.A. \& Fried, J., 2003, 'Executive compensation as an agency problem', Journal of Economic Perspectives 17(3), 71-92. https://doi.org/10.1257/ 089533003769204362

Bebchuk, L.A. \& Fried, J.M., 2006, 'Pay without performance: Overview of the issues' Academy of Management Perspectives 20(1), 5-24. https://doi.org/10.5465/ amp.2006.19873407

Bhagat, S. \& Bolton, B., 2014, 'Financial crisis and bank executive incentive compensation', Journal of Corporate Finance 25(C), 313-341. https://doi.org/ 10.1016/j.jcorpfin.2014.01.002

Bloomberg, L.P., 2018, Research domain. Subscription Service.

Bohler-Muller, N., Roberts, B.J., Struwig, J., Gordon, S.L., Radebe, T. \& Alexander, P., 2017 , 'Minding the protest. Attitudes towards different forms of protest action in contemporary South Africa', South Africa Crime Quarterly 62, 81-92. https://doi. org/10.17159/2413-3108/2017/v0n62a3041

Bradley, S., 2013, 'The relationship between CEO compensation and company performance in a South African context', Journal of Economic and Financial Sciences 6(3), 539-564. https://doi.org/10.4102/jef.v6i3.247

Brandes, P., Goranova, M. \& Hall, S., 2008, 'Navigating shareholder influence: Compensation plans and the shareholder approval process', Academy of Management Perspectives 22(1), 41-57. https://doi.org/10.5465/amp.2008. 31217511

Burns, N. \& Kedia, S., 2006, 'The impact of performance-based compensation on misreporting', Journal of Financial Economics 79(1), 35-67. https://doi.org/ 10.1016/j.jineco.2004.12.003

Bussin, M., 2015a, 'CEO pay-performance sensitivity in the South African context', South African Journal of Economic and Management Sciences 18(2), 232-244. https://doi.org/10.4102/sajems.v18i2.838

Bussin, M., 2015b, 'The relationship between chief executive officer remuneration and financial performance in South Africa between 2006 and 2012', SA Journal of Human Resource Management 13(1), 1-18. https://doi.org/10.4102/sajhrm. Human Resol
v13i1.668

Bussin, M., 2018, 'Chief executive officer compensation sensitivity in the South African mining industry', Acta Commercii 18(1), a573, viewed 13 April 2019, from https:// doi.org/10.4102/ac.v18i1.573

Bussin, M. \& Blair, C., 2015, 'Financial indicators of company performance in different industries that affect CEO remuneration in South Africa', South African Journal of Economic and Management Sciences 18(4), 534-550. https://doi.org/10.4102/ sajems.v18i4.1249

Bussin, M. \& Modau, M.F., 2015, 'The relationship between chief executive officer remuneration and financial performance in South Africa between 2006 and 2012' SA Journal of Human Resource Management 13(18), 1-18. https://doi.org/ 10.4102/sajhrm.v13i1.668

Bussin, M. \& Nel, M., 2015, 'Relationship between CEO remuneration and company financial performance in the South African retail and consumer goods sector', Acta Commercii 15(1), 1-11. https://doi.org/10.4102/ac.v15i1.240

Cadman, B. \& Carter, M.E., 2014, 'Compensation peer groups and their relation with CEO pay', Journal of Management Accounting Research 26(1), 57-82. https://doi. org/10.2308/jmar-50598

Cai, J. \& Walkling, R.A., 2011, 'Shareholders' say on pay: Does it create value?', Journal of Financial and Quantitative Analysis 46(2), 299-339. https://doi.org/10.1017/ \$0022109010000803
Cai, J., Garner, J. \& Walkling, R.A., 2010, 'Shareholder access to the boardroom: A survey of recent evidence', Journal of Applied Finance 20(2), 15-26.

Conyon, M. \& Sadler, G., 2010, 'Shareholder voting and directors' remuneration report legislation: Say on pay in the UK', Corporate Governance: An Internationa Review 18(4), 296-312. https://doi.org/10.1111/j.1467-8683.2010.00802.x

Core, J.E., Guay, W. \& Larcker, D.F., 2008, 'The power of the pen and executive compensation', Journal of Financial Economics 88(1), 1-25. https://doi.org/ 10.1016/j.jfineco.2007.05.001

Corkery, J. \& Medarevic, S., 2013, 'Executive remuneration under scrutiny: The cutting edge of the "shareholder spring"', Corporate Governance 1(1), 1-16. https://egej. scholasticahq.com/article/6925.

Davids, E. \& Ntamane, X., 2017, 'South Africa', in F.J. Aquila (ed.), In the shareholder rights and activism review, pp. 100-109, 2nd edn., Gideon Roberton, London.

Del Guercio, D., Seery, L. \& Woidtke, T., 2008, 'Do boards pay attention when institutional investor activists "just vote no"?', Journal of Financial Economics 90(1), 84-103. https://doi.org/10.1016/j.jfineco.2008.01.002

De Wet, J.H.vH., 2012, 'Executive compensation and the EVA and MVA performance of South African listed companies', Southern African Business Review 16(3), 57-80.

Devers, C.E., Cannella, A.A., Reilly, G.P. \& Yoder, M.E., 2007, 'Executive compensation: A multidisciplinary review of recent developments', Journal of Management 33(1), 1016-1072. https://doi.org/10.1177/0149206307308588

Deysel, B. \& Kruger, J., 2015, 'The relationship between South African CEO compensation and company performance in the banking industry', Southern African Business Review 19(1), 137-169. https://doi.org/10.25159/1998-8125/5837

Elo, S. \& Kyngäs, H., 2007, 'The qualitative content analysis process', Journal of Advanced Nursing 62(1), 107-115. https://doi.org/10.1111/j.1365-2648.2007.04569.x

Edmans, A. \& Gabaix, X., 2009, 'IS CEO pay really inefficient? A survey of new optimal contracting theories', European Financial Management 15(3), 486-496. https:// doi.org/10.1111/j.1468-036X.2009.00500.x

Ertimur, Y., Ferri, F. \& Muslu, V., 2011, 'Shareholder activism and CEO pay', The Review of Financial Studies 24(2), 535-592. https://doi.org/10.1093/rfs/hhq113

Faulkender, M., Kadyrzhanova, D., Prabhala, N. \& Senbet, L., 2010, 'Executive compensation: An overview of research on corporate practices and proposed reforms', Journal of Applied Corporate Finance 22(1), 107-118. https://doi. reforms', Journal of Applied Corporate
org/10.1111/j.1745-6622.2010.00266.x

Ferri, F. \& Sandino, T., 2009, 'The impact of shareholder activism on financial reporting and compensation: The case of employee stock options expensing', The Accounting Review 84(2), 433-466. https://doi.org/10.2308/accr.2009.84.2.433

Gantchev, N., 2013, 'The costs of shareholder activism: Evidence from a sequential decision model', Journal of Financial Economics 107(3), 610-631. https://doi. org/10.1016/j.jfineco.2012.09.007

Gantchev, N. \& Giannetti, M., 2019, 'The costs and benefits of shareholder democracy', SMU Cox School of Business Research Paper No. 18-35; Swedish House of Finance Research Paper No. 18-15; European Corporate Governance Institute (ECGI) Finance Working Paper No. 586/2018, viewed 13 April 2019, from SSRN: https:// doi.org/10.2139/ssrn.3269378

Gifford, E.J.M., 2010, 'Effective shareholder engagement: The factors that contribute to shareholder salience', Journal of Business Ethics 92(suppl 1), 79-97. https://doi. org/10.1007/s10551-010-0635-6

Gillan, S.L. \& Starks, L.T., 2000, 'Corporate governance proposals and shareholder activism: The role of institutional investors', Journal of Financial Economics 57(2), 275-305. https://doi.org/10.1016/S0304-405X(00)00058-1

Goranova, M. \& Ryan, L.V., 2014, 'Shareholder activism: A multidisciplinary review', Journal of Management 40(5), 1230-1268. https://doi.org/10.1177/014920 6313515519

Hooghiemstra, R., Kuang, Y.F. \& Qin, B., 2015, 'Say-on-pay votes: The role of the media', European Accounting Review 24(4), 753-778. https://doi.org/10.1080/09 638180.2015 .1034152

Institute of Directors in Southern Africa (IODSA), 2016, King IV report on corporate governance for South Africa, viewed 14 April 2019, from https://c.ymcdn.com/ sites/www.iodsa.co.za/resource/resmgr/king_iv/King_IV_Report/loDSA_King_ IV_Report_-_WebVe.pdf.

Jansson, M. \& Biel, A., 2011, 'Motives to engage in sustainable investment: A comparison between institutional and private investors', Sustainable Development 19(2), 135-142. https://doi.org/10.1002/sd.512

Jensen, M.C. \& Meckling, W.H., 1976, 'Theory of the firm: Managerial behavior, agency costs and ownership structure', Journal of Financial Economics 3(4), 305agency costs and ownership structure', Journal of Fin
360. https://doi.org/10.1016/0304-405X(76)90026-X

Keke, A., 2017, 'Executive directors: Practices and remuneration trends report', PricewaterhouseCoopers, 9th edn., viewed 13 April 2019, from https://www.pwc. co.za/en/assets/pdf/executive-directors-report-2017.pdf.

Kuhnen, C. \& Niessen, A., 2012, 'Public opinion and executive compensation', Management Science 8(7), 1249-1272. https://www.jstor.org/stable/41499555.

Kidder, D.L. \& Buchholtz, A.K., 2002, 'Can excess bring success? CEO compensation and the psychological contract', Human Resource Management Review 12(4), 599-617. https://doi.org/10.1016/S1053-4822(02)00071-2

Kimbro, M.B. \& Xu, D., 2016, 'Shareholders have a say in executive compensation: Evidence from say-on-pay in the United States', Journal of Accounting and Public Policy 35(1), 19-42. https://doi.org/10.1016/j.jaccpubpol.2015.08.003

Liu, J. \& Taylor, D., 2008, 'Legitimacy and corporate governance determinants of executives' remuneration disclosures', Corporate Governance: The International Journal of Business in Society 8(1), 59-72. https://doi.org/10.1108/14720700 810853400 
Madlela, V. \& Cassim, R., 2017, 'Disclosure of directors' remuneration under South African company law: Is it adequate?', The South African Law Journal 134(2) 383-414.

Marens, R., 2002, 'Inventing corporate governance: The mid-century emergence of shareholder activism', Journal of Business \& Management 8(4), 365-390. https:// doi.org/10.5465/apbpp.2002.7517511

Masiya, T., 2014, 'Social movement trade unionism: Case of the Congress of South African Trade Unions', Politikon 41(3), 443-460. https://doi.org/10.1080/02589346. 2014.975932

Mchunu, S., 2019, 'Shareholders get tough on executive pay', Business Report, 08 July, viewed 16 August 2019, from https://www.iol.co.za/business-report/companies/ shareholders-get-tough-on-executive-pay-28875344.

Nordén, L. \& Strand, T., 2011, 'Shareholder activism among portfolio managers: Rational decision or 15 minutes of fame?', Journal of Management Governance 15(3), 375-391. https://doi.org/10.1007/s10997-009-9114-9

Nzukuma, K.C.C. \& Bussin, M., 2011, 'Job-hopping amongst African Black senior management in South Africa: Original research', SA Journal of Human Resource Management 9(1), 1-12. https://doi.org/10.4102/sajhrm.v9i1.360

Oberholzer, M. \& Theunissen, M., 2012, 'Benchmarking of Johannesburg Stock Exchange CEO compensation', International Business and Economics Research Journal 11(9), 1061-1076. https://doi.org/10.19030/iber.v11i9.7189

PwC, 2018, Executive directors practices and remuneration trends report, viewed 13 April 2019, from https://www.pwc.co.za/en/assets/pdf/2018-executivedirectors-report.pdf.

Reid, M. \& Toffel, M.W., 2009, 'Responding to public and private politics: Corporate disclosure of climate change strategies', Strategic Management Journal 30(11), 1157-1178. https://doi.org/10.1002/smj.796

Schnatterly, K., Shaw, K.W. \& Jennings, W.W., 2008, 'Information advantages of large institutional owners', Strategic Management Journal 29(2), 219-227. https://doi. org/10.1002/smj.654

Scholtz, H. \& Smit, A., 2012, 'Executive remuneration and company performance for South African companies listed on the Alternative Exchange (AltX)', Southern African Business Review 16(1), 22-38.
Seccombe, A., 2013, 'Mining executives' pay packets questioned by funds', Business Day, 31 October, viewed 26 June 2019, from https://www.businesslive.co.za/bd/ companies/mining/2013-10-31-mining-executives-pay-packets-questioned-byfunds/.

Stathopoulos, K. \& Voulgaris, G., 2016, 'The importance of shareholder activism: The case of say-on-pay', Corporate Governance: An International Review 24(3), 359-370. https://doi.org/10.1111/corg.12147

Statistics South Africa, 2017, Poverty trends in South Africa: An examination of absolute poverty between 2006 and 2015, viewed 20 June 2019, from https:// www.statssa.gov.za/?p=10341.

Thomas, R.S. \& Martin, K.J., 1999, 'The effect of shareholder proposals on executive compensation', University of Cincinnati Law Review 67(4), 1021-1081. https:// doi.org/10.2139/ssrn.160188

The World Bank in South Africa, 2018, Overview, viewed 20 June 2019, from https:// www.worldbank.org/en/country/southafrica/overview.

Viviers, S., 2015, 'Executive remuneration in South Africa: Key issues highlighted by shareholder activists', African Journal of Business Ethics 9(1), 6-32. https://doi. org/10.15249/9-1-112

Viviers, S., Mans-Kemp, N. \& Fawcett, R., 2017, 'Mechanisms to promote board gender diversity in South Africa', Acta Commercii 17(1), a489, viewed 20 June 2019, from https://doi.org/10.4102/ac.v17i1.489

Viviers, S. \& Smit, E.v.d.M., 2015, 'Institutional proxy voting in South Africa: Process, outcomes and impact', South African Journal of Business Management 46(3), 23-34. https://doi.org/10.4102/sajbm.v46i4.106

Watson, W., 2007, Brick by brick: An informal guide to the history of South Africa, New Africa Book, Claremont, CA.

Yamahaki, C. \& Frynas, J.G., 2016, 'Institutional determinants of private shareholder engagement in Brazil and South Africa: The role of regulation', Corporate Governance: An International Review 24(5), 509-527. https://doi.org/10.1111/ corg.12166

Yocam, E. \& Choi, A., 2010, Corporate governance: A board director's pocket guide: Leadership, diligence, and wisdom, iUniverse Books, Bloomington, IN. 